\title{
A IMPORTÂNCIA DO ORÇAMENTO PÚBLICO: A PARTICIPAÇÃO DA POPULAÇÃO DE APODI-RN NA ELABORAÇÃOO DO PLANEJAMENTO ORÇAMENTÁRIO
}

\author{
R. R. D. LIMA e J. P. MEDEIROS \\ Instituto Federal de Educação, Ciência e Tecnologia do Rio Grande do Norte \\ rayanedantaslima@gmail.com; jassio.pereira@ifrn.edu.br \\ Artigo submetido em 25/07/2018 e aceito em 01/08/2018 \\ DOI: 10.15628/empirica.2018.7538
}

\section{RESUMO}

A Gestão Pública no Brasil tende a incorporar práticas de participação da população nas decisões políticas, tornando-se mais democrática. Dentre essas, é possível citar o modelo do Orçamento Participativo na elaboração do orçamento público. Nesta conjuntura, o presente estudo busca analisar o contexto de participação da população no planejamento orçamentário da cidade de Apodi-RN, partindo do pressuposto de que, com a participação da população, o orçamento torna-se mais eficaz. Trata-se de uma pesquisa de caráter exploratório-descritivo, que utilizou o método do estudo de caso, enquanto a forma de abordar o problema pode ser classificada como quali-quantitativa. Como instrumentos de coletas de dados, foram utilizados um questionário e uma entrevista, do tipo focalizada. 0 universo da pesquisa foi formado pelo total de eleitores e, como amostra, um total de 380 cidadãos com idade apta para votar. 0 resultado da pesquisa comprovou que o planejamento orçamentário realizado no município alvo de estudo não dispõe de muitas oportunidades de participação nas decisões relativas à execução dos recursos públicos e, consequentemente, grande parcela dos cidadãos não participam da elaboração do orçamento público. Constatou-se, também, que a maioria das pessoas desconhece o tema, e, portanto, não sabem como, e se, podem contribuir no planejamento orçamentário municipal. Dessa forma, pode-se comprovar, por meio das respostas dos cidadãos, que a gestão municipal não disponibiliza maneiras específicas de participação popular no planejamento orçamentário, além disso, o incentivo à participação da população é pouco e não atende a parcela significativa dos cidadãos, carecendo de ações para agregar a sociedade nas decisões orçamentárias.

Palavras-Chaves: Orçamento Público, Orçamento Participativo, Democracia, Gestão Pública.

\section{ABSTRACT}

Public Management in Brazil tends to incorporate population communion practices in political decisions, becoming more democratic. Among these, it is possible to quote the Participatory Budget model in the public budget elaboration. At this juncture, the present study seeks to analyze the context of population involvement in the budget planning of Apodi-RN city, based on the assumption that the budget becomes more effective with the population communion. It's about an exploratory-descriptive 
research that used the case study method, while the way of approaching the problem can be classified as quali-quantitative. As instruments of data collection, a questionnaire and an focused interview were used. The research universe was formed by the total number of voters and, as a sample, a total of 380 citizens of voting age. The result of the research proved that the budget planning of the study target county doesn't has many opportunities to take part in decisions concerning of public resources execution, and, thereafter, a large citizens quota do not get involved in the public budget preparation. It was also noted that most people are unaware of the issue, and therefore do not know how, and if, they can contribute to municipal budget planning. In this way, it can be verified, through the citizens' answers, that county management does not provide specific ways of popular participation in budget planning, in addition, the population communion is scarce and does not serve the majority of citizens, lacking of public policies to aggregate society in budget decisions.

Keywords: Public Budget, Participatory Budgeting, Democracy, Public Management.

\section{INTRODUÇÃO}

A atividade financeira é exercida pelo Estado para atender às demandas da população, por meio da prestação dos serviços públicos. Sobre tal atividade financeira, Paludo $(2013$, p.32) define orçamento público como "[...] uma lei que, entre outros aspectos, exprime, em termos financeiros, a alocação dos recursos públicos, é um documento legal que contém a previsão de receitas e a fixação de despesas a serem realizadas por um governo, em um determinado exercício financeiro". É por meio do orçamento público que se planejam e executam as finanças públicas.

Nesse sentido, o Estado deve planejar e executar seus atos para atingir metas satisfatórias, e que atendam aos princípios do orçamento público, como legalidade, impessoalidade, anualidade, exclusividade, clareza, publicidade, entre outros. No Brasil, a gestão de finanças se dá por meio de três leis: Plano Plurianual (PPA), Lei de Diretrizes Orçamentárias (LDO) e Lei Orçamentária Anual (LOA).

Como é função do orçamento público atender à sociedade, de forma transparente e objetiva, é imprescindível que as pessoas tenham maior participação no planejamento orçamentário. Surge, então, o Orçamento Participativo (OP). Este tem como intuito ampliar a democracia, por meio da atuação direta dos cidadãos nas propostas orçamentárias. Paludo (2013, p.38) descreve OP como "[...] uma técnica orçamentária em que a alocação de alguns recursos contidos no orçamento público é decidida com a participação direta da população, ou através de grupos organizados da sociedade civil, como a associação de moradores".

Um dos benefícios do Orçamento Participativo (OP) é a democratização da relação entre Estado e sociedade. É por meio desse tipo de orçamento que o cidadão deixa de ser apenas um ator passivo e passa a ter um papel ativo na gestão pública. Além disso, o OP também estimula o papel democrático da população, o exercício da cidadania e o compromisso com o bem público, além de garantir a transparência da gestão pública.

Implantar o OP em um município também contribui para o esclarecimento das despesas públicas, além de proporcionar, à população, conhecimento sobre os principais problemas enfrentados pela comunidade. 
Também é por meio desse instrumento que pode ser reduzida práticas clientelistas (favorecimento de uma determinada pessoa ou grupo de pessoas), promovendo uma gestão orçamentária transparente.

Práticas de administração associadas ao orçamento participativo são encontradas, com mais facilidade, em âmbito municipal, e é por meio dessa técnica que a população interessada decide as prioridades de investimentos. Nesse contexto, a cidade estudada, Apodi, é um município do estado do Rio Grande do Norte, emancipada em 1835, e localizada na microrregião Chapada do Apodi, na mesorregião Oeste Potiguar. A economia é fundamentada nas atividades: indústria, agropecuária e comércio e, de acordo com os levantamentos do Instituto Brasileiro de Geografia e Estatística, possui um total de 34.763 habitantes no ano de 2010, e um percentual de $88,92 \%$ eleitores, com idade entre 18 e 69 anos (IBGE, 2017).

Partindo desse cenário, tem-se como problema da presente pesquisa: como se apresenta o contexto de participação da população na elaboração do orçamento do município de Apodi-RN? A hipótese de partida é que, com uma real participação da população, o orçamento torna-se mais eficaz, logo, o ideal seria a atuação de toda a sociedade nesse processo.

Neste sentido, esta pesquisa tem como objetivo geral analisar o contexto de participação da população no planejamento orçamentário da cidade de Apodi-RN. De maneira mais específica buscouse verificar o modelo de elaboração do orçamento público no município; verificar o envolvimento da população no planejamento orçamentário; averiguar a existência de ações voltadas ao incentivo à participação da população e, por fim, identificar a expectativa dos cidadãos quanto aos aspectos positivos e negativos do orçamento participativo do município.

Em relação à importância desse estudo para a sociedade, têm-se o conhecimento de uma gestão orçamentária participativa, a divulgação de como a população pode atuar junto ao poder municipal para tomada de decisões de investimentos, e assim, contribuir para democratização da relação EstadoSociedade.

Quanto a sua contribuição organizacional, o presente estudo trata de um tema relevante para a prefeitura, já que essa pesquisa pode demonstrar se as formas de participação social aplicadas atualmente são eficazes, além de seus benefícios serem amplamente discutidos, dessa forma, gerar novas ideias para a gestão orçamentária participativa.

Após esta introdução, serão apresentados, na sequência, a revisão da literatura que balizou o estudo ora desenvolvido, discutindo aspectos do orçamento público e da participação da população em sua construção. Em seguida, descreve-se os procedimentos metodológicos utilizados, seguidos da análise de dados e suas respectivas conclusões.

\section{ORÇAMENTO PÚBLICO}

\subsection{Tipos de orçamentos e princípios orçamentários}

O Estado brasileiro é a pessoa jurídica de direito público responsável por empregar os recursos públicos em prol do bem estar da sociedade, fornecendo principalmente, serviços de natureza básica, como 
saúde, educação, segurança entre outros. Para isso, é preciso gerir suas receitas e despesas, atendendo a legislação vigente e os direitos dos cidadãos, assim, tem-se a realização do orçamento público.

O orçamento público, segundo Carvalho (2014, p. 28), "é um processo contínuo, dinâmico e flexível, que traduz, em termos financeiros, para determinado período (um ano), os planos e programas de trabalho do governo. [...] 0 orçamento público é um instrumento de planejamento e execução das finanças públicas.".

Para Carvalho (2014), o orçamento, na administração pública, representa um dos mais antigos instrumentos de planejamento e execução das finanças públicas, e esteve em constante evolução, acompanhando as tendências mundiais, mesmo que lentamente. Esse orçamento público pode receber diferentes classificações, como descreve Paludo (2013, p. 33) no quadro a seguir:

Quadro 1: Tipos de orçamentos

\begin{tabular}{|l|l|}
\hline \multicolumn{1}{|c|}{ TIPOS DE ORÇAMENTOS } & \multicolumn{1}{c|}{ CONCEITOS } \\
\hline Orçamento Tradicional/clássico & $\begin{array}{l}\text { É um documento de previsão de receita e autorização de despesas com ênfase no } \\
\text { gasto. É um processo orçamentário em que apenas uma dimensão do orçamento } \\
\text { é explicitada, qual seja, o objeto de gasto. }\end{array}$ \\
\hline $\begin{array}{l}\text { Orçamento de Desempenho/ } \\
\text { Funcional }\end{array}$ & $\begin{array}{l}\text { A ênfase é no desempenho organizacional, e avaliam-se os resultados (em termos } \\
\text { de eficácia - não de efetividade). Procura-se medir o desempenho através do } \\
\text { resultado obtido, tornando o orçamento um instrumento de gerenciamento para a } \\
\text { administração pública. }\end{array}$ \\
\hline Orçamento Programa & $\begin{array}{l}\text { É um plano de trabalho que integra - numa concepção gerencial - planejamento } \\
\text { e orçamento com objetivos e metas a alcançar. A ênfase do orçamento-programa } \\
\text { é nas realizações e a avaliação de resultados, abrange a eficácia (alcance das } \\
\text { metas) e a efetividade (análise do impacto final das ações). }\end{array}$ \\
\hline Orçamento Base-Zero & $\begin{array}{l}\text { Cada despesa é tratada como uma nova iniciativa de despesa, e a cada ano } \\
\text { é necessário provar as necessidades de orçamento, competindo com outras } \\
\text { prioridades e projetos. Inicia-se todo ano, partindo do "zero" - daí o nome } \\
\text { Orçamento Base-Zero. A ênfase é na eficiência. }\end{array}$ \\
\hline Orçamento Participativo & $\begin{array}{l}\text { O Orçamento Participativo é uma técnica orçamentária em que a alocação de } \\
\text { alguns recursos contidos no Orçamento Público é decidida com a participação } \\
\text { direta da população, ou através de grupos organizados da sociedade civil. Até o } \\
\text { momento, sua aplicação restringe-se ao âmbito municipal. }\end{array}$ \\
\hline
\end{tabular}

Fonte: Paludo (2013).

Quanto aos princípios orçamentários, Paludo (2013) diz que eles representam regras válidas para todo o processo orçamentário, isto é, para a elaboração, a execução e o controle/avaliação. Ainda segundo o autor, tais princípios visam assegurar, ao processo orçamentário, racionalidade, eficiência e transparência, sem ter, contudo, um caráter absoluto, tendo em vista suas exceções.

Como princípios orçamentários tem-se, Unidade/Totalidade, Universalidade, Anualidade, Exclusividade, Especificação, Publicidade, Orçamento Bruto, Não afetação de receitas, Equilíbrio e Programação, entre outros.

No segundo quadro constam os princípios orçamentários e os conceitos de acordo com Santos (2012, p. 41-42): 
Quadro 2: Princípios orçamentários

\begin{tabular}{|c|c|}
\hline PRINCÍPIOS & CONCEITOS \\
\hline Princípio da Unidade/Totalidade & $\begin{array}{l}\text { Deve haver uma só LOA para cada entidade da Federação (União, Estados e } \\
\text { municípios). }\end{array}$ \\
\hline Princípio da Universalidade & $\begin{array}{l}\text { A LOA deve conter todas as despesas e receitas da Administração pública, } \\
\text { englobando todos os poderes, os fundos, os órgãos e as entidades da } \\
\text { Administração Pública. }\end{array}$ \\
\hline Princípio da Anualidade & $\begin{array}{l}\text { As receitas e despesas constantes da LOA devem se reportar a um período } \\
\text { determinado, em geral um exercício financeiro, e os correspondentes devem ter } \\
\text { sua vigência adstrita ao exercício financeiro. }\end{array}$ \\
\hline Princípio da Exclusividade & $\begin{array}{l}\text { A LOA não pode conter dispositivo estranho à previsão da receita e à fixação da } \\
\text { despesa. }\end{array}$ \\
\hline Princípio da Especificação & $\begin{array}{l}\text { A LOA não poderá consignar dotações globais e despesas, devendo fornecer } \\
\text { detalhamento suficiente para demonstrar a origem e a aplicação dos recursos. }\end{array}$ \\
\hline Princípio da Publicidade & $\begin{array}{l}\text { A LOA, seus créditos e os atos relativos à sua elaboração e execução devem ser } \\
\text { divulgados para conhecimento público e serem acessíveis a qualquer cidadão } \\
\text { para consulta. }\end{array}$ \\
\hline Princípio do Orçamento Bruto & $\begin{array}{l}\text { A LOA deve conter as receitas e despesas pelos seus valores brutos, sem } \\
\text { qualquer tipo de dedução prévia. }\end{array}$ \\
\hline Princípio da Não Afetação de Receitas & $\begin{array}{l}\text { As receitas constantes da LOA deverão estar livres de comprometimento prévio } \\
\text { a determinados gastos, sendo vedada a vinculação de receitas de impostos a } \\
\text { órgão, fundo ou despesa. }\end{array}$ \\
\hline Princípio do Equilíbrio & $\begin{array}{l}\text { As receitas constantes da LOA não devem exceder as despesas previstas para } \\
\text { o exercício financeiro. }\end{array}$ \\
\hline Princípio da Programação & $\begin{array}{l}\text { As receitas e despesas constantes da LOA deverão ser organizadas de modo } \\
\text { a veicular a programação de trabalho do governo, seus objetivos, suas metas e } \\
\text { suas ações. }\end{array}$ \\
\hline
\end{tabular}

Fonte: Santos (2012).

Os princípios orçamentários são considerados uma exigência ética do processo orçamentário e imprescindíveis para torná-lo legítimo. Ao respeitar os princípios na elaboração do orçamento, têmse maior probabilidade de atender o interesse geral, já que interesses individuais podem ser evitados. Como visto, conhecer os princípios orçamentários possibilita exercer com mais eficácia o controle e, ao mesmo tempo, tais princípios são essenciais para guiar todo o ciclo orçamentário.

\subsection{Ciclo orçamentário}

A Constituição Federal de 1988 estabelece que Leis de iniciativa do Poder Executivo estabelecerão os seguintes instrumentos de planejamento (art. 165, incisos I, II e III).

- Plano Plurianual (PPA);

- Diretrizes Orçamentárias (LDO);

- Orçamentos anuais (LOA).

Tal planejamento é importante para definir as prioridades e ações que serão empregadas para sanar os problemas da sociedade, dentro dos limites de gastos do Estado. Segundo Silva (2009) o 
processo de planejamento governamental deve expressar com maior veracidade a responsabilidade do Governo para com a sociedade, sendo assim, o orçamento deve ter seus objetivos claros.

Os instrumentos de planejamento são integrados, por exemplo, para que uma despesa conte na LOA, deve está presente na LDO e PPA. O Plano Plurianual estabelecerá, de forma regionalizada, as diretrizes, objetivos e metas da administração pública federal para as despesas de capital e outras delas decorrentes e para as relativas aos programas de duração continuada (art. 165, § $1^{\circ}$ da CF). 0 PPA corresponde ao plano de governo, com duração de quatro anos e é elaborado no primeiro ano de mandato. É o instrumento de planejamento de médio prazo e todas as ações e objetivos devem está presentes no PPA para que possam ser citados nos demais instrumentos de planejamento.

Já a Lei de Diretrizes Orçamentárias compreenderá as metas e prioridades da administração pública federal, incluindo as despesas de capital para o exercício financeiro subsequente, orientará a elaboração da lei orçamentária anual, disporá sobre as alterações na legislação tributária e estabelecerá a política de aplicação das agências oficiais de fomento (art. 165, § $2^{\circ}$ da CF). A LDO seleciona quais metas do PPA integrarão o orçamento anual, é uma lei orçamentária de curto prazo.

A Lei Orçamentária Anual compreenderá, por sua vez, o orçamento fiscal referente aos Poderes da União, seus fundos, órgãos e entidades da administração direta e indireta, inclusive fundações instituídas e mantidas pelo poder público; orçamento de investimentos de empresas em que a União, direta ou indiretamente, detenha a maioria do capital social com direito a voto; orçamento da seguridade social, abrangendo todas as entidades e órgãos a ela vinculados, da administração direta ou indireta, bem como os fundos e fundações instituídos e mantidos pelo Poder Público (art. 165, § $5^{\circ}$ da CF). A LOA concretiza o planejado no PPA, obedecendo às orientações da LDO. É por meio da LOA que as despesas do exercício são executadas.

Referente ao ciclo orçamentário, Carvalho (2014, p. 223) esclarece que:

O ciclo orçamentário não se confunde com o exercício financeiro, haja vista que aquele (ciclo orçamentário) envolve um período mais amplo e mais complexo do que o exercício financeiro. 0 ciclo orçamentário desenvolve-se basicamente nas sete etapas seguintes: elaboração e revisão do PPA; elaboração e revisão de outros planos; elaboração do projeto da LDO; elaboração do projeto de lei da LOA; apreciação, aprovação, sanção e publicação da LOA; execução; controle e avaliação.

Sabendo que o orçamento é realizado pelo poder executivo, no entanto, o poder legislativo deve aprovar o orçamento para que este possa ser executado e, ao final do processo, ocorre o controle e avaliação dos gastos públicos, no qual também ocorre a participação do poder Legislativo, juntamente com o Tribunal de Contas.

No ciclo orçamentário pode ocorrer a participação da população, geralmente na fase de controle, quando são apresentados os gastos públicos. No entanto, no modelo "orçamento participativo", a sociedade pode opinar desde o planejamento, nas decisões de investimentos de recursos. 


\subsection{Orçamento Participativo}

De acordo com Almeida (2005), devido a diversas transformações na sociedade brasileira, propiciadas pelo avanço da democratização e da diferenciação social aliado à valorização da democracia participativa, tornou-se mais importante à participação da sociedade civil na gestão da coisa pública, e o orçamento participativo é utilizado para esse fim.

O Orçamento Participativo - OP é um importante instrumento de participação da população na gestão pública. Para Carvalho (2014, p.50),

Orçamento participativo é um mecanismo governamental de democracia participativa que permite aos cidadãos influenciar ou decidir sobre os orçamentos públicos, geralmente quanto ao orçamento de investimentos (construção de unidades hospitalares, aquisição de bens etc.). Geralmente este ocorre através da participação da comunidade mediante assembleias abertas e periódicas e etapas de negociação direta com o governo.

Seguindo a mesma linha de pensamento, Oliveira (2013, p.45), considera o OP como "uma política pública destinada a incluir a sociedade no processo de alocação do orçamento público". 0 autor também diz que o OP pode ser entendido como um meio para transformação social ou para ampliar as práticas de "boa governança" do poder executivo. Governança é a maneira pelo qual o poder é exercido na administração pública, ou seja, a forma como os recursos são executados e as exigências da população, atendidas. Estender uma parte desse poder para a população significa obter maior índice de confiança e apoio desta.

Para Wampler (2007), o OP é um programa inovador, pois incentiva a participação através da distribuição de recursos para cada uma das regiões do município em função da mobilização da população, e estabelece novos mecanismos de responsabilização dos gestores públicos.

No Brasil a técnica orçamentária utilizada é o orçamento programa, e a população atua no planejamento orçamentário por meio de políticas de orçamento participativo. Como se pode ver na Lei de Responsabilidade Fiscal, art. 48, parágrafo único: "a transparência será assegurada também mediante incentivo à participação popular e realização de audiências públicas, durante os processos de elaboração e de discussão dos planos, Lei de Diretrizes orçamentárias e orçamentos". Essas leis servem como incentivo para a abertura da gestão democrática do orçamento público e, portanto, são essenciais para incluir a sociedade nesse processo.

As principais características do OP apontadas por Carvalho (2014, p. 52) são:

- Gerar decisões públicas e evitar que os governantes priorizem interesses particulares;

- O cidadão participa diretamente do planejamento orçamentário, ou seja, passa a ser um ator ativo;

- Instrumento de democracia.

No Brasil, o Orçamento Participativo é uma experiência nova, necessita de ajuste contínuo e de ser difundido nos municípios brasileiros. Para isso, é preciso que os gestores públicos compreendam sua importância para enriquecer a democracia e assim, implante o OP. A criação de organizações não governamentais também seria uma solução para a propagação dessa prática (COSTA, 2014). 


\section{ISSN - 2447-178X}

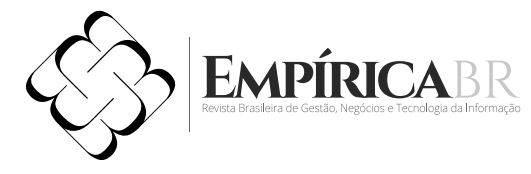

De uma maneira geral, o Orçamento Participativo é um importante mecanismo de democracia participativa, pois oferece ao cidadão opinar ou decidir diretamente sobre os orçamentos públicos, de como serão investidos os recursos públicos, afinal, é o cidadão quem mais conhece os problemas da cidade. De acordo com Streck (2003, p.122) "o orçamento participativo propõe-se a ser um instrumento do poder executivos de escuta das comunidades, de prestação de contas e de fiscalização do estado por parte da comunidade".

O OP une práticas de democracia participativa e democracia representativa, ou seja, depende da participação da população e que os gestores municipais deem condições reais de participação e assegurem o cumprimento das políticas públicas definidas nas assembleias. A gestão orçamentária participativa é assegurada pelo Estatuto das Cidades (Lei 10.257), em seu artigo 44, o qual visa interligar a elaboração do orçamento público a participação popular, conforme descrito no trecho a seguir.

No âmbito municipal, a gestão orçamentária participativa de que trata a alínea f do inciso III do art. 4-desta Lei incluirá a realização de debates, audiências e consultas públicas sobre as propostas do plano plurianual, da lei de diretrizes orçamentárias e do orçamento anual, como condição obrigatória para sua aprovação pela Câmara Municipal.

Como apontado por Fonseca (2009), o cidadão, ao definir as prioridades de investimentos dos recursos públicos, desperta neles o sentimento de responsabilidade com a coisa pública e de obrigação social, ocorrendo, assim, um esforço conjunto, entre governo e população, para alcançarem o bemestar da coletividade.

Este instrumento se mostra como elemento de democracia também por inserir a população mais carente, que sempre estiveram à margem das decisões políticas por não serem considerados influentes nesse meio. De acordo com Souza (2001, p.94), "Nesse sentido, o mérito do OP parece não estar necessariamente nos ganhos materiais para segmentos de baixa renda, mas sim na ampliação da participação e do poder de decisão para grupos anteriormente excluídos do processo decisório". Além disso, o OP é capaz de proporcionar um acompanhamento mais eficaz aos gastos públicos, responsabilizando os governantes que gerenciá-los de forma inadequada.

Além disso, a ação de se envolver com as questões da coletividade, contribuindo para o bemestar da sociedade, e conhecendo seus direitos e deveres é o que se pode entender como consciência cidadã. A interação dos cidadãos nas decisões do município pode ser despertada por meio de políticas públicas que busquem essa inter-relação. O OP pode ser associado, portanto, ao empoderamento, accountability, planejamento urbano, entre outros, de maneira que a disseminação dessa prática nos municípios torna-se cada vez mais importante.

Para Frey (2004), os novos modelos de gestão e administração pública disseminam o conhecimento disponível na sociedade através de um processo interativo. A aprendizagem social contribui, assim, para a construção de valores éticos e coletivos, como a cidadania. Nesse sentido, para Costa (2014), o OP pode incrementar novas habilidades nos atores envolvidos, despertando uma consciência coletiva 
maior e gerando ganhos potenciais ao longo do tempo. De forma semelhante, Villas-Boas (1994) considera o orçamento participativo como um meio que possibilita a criação de uma nova cultura política, pois aumenta a conscientização da cidadania e gera melhorias na vida da população. É importante ressaltar, contudo, que os ganhos com a participação popular no orçamento podem não ser expressivos e imediatos, mas, ao longo do tempo podem contribuir para uma sociedade mais ativa na gestão política, com a representação de uma parcela maior da população e de todas as classes sociais.

De acordo com Benevides (1996) para implantação de técnicas que promovam a participação da sociedade de forma mais ativa, existem dificuldades de representação, imposição de costumes que limitam essa participação e preconceito contra a participação direta da sociedade. Outra dificuldade encontrada é em relação ao envolvimento dos gestores municipais nesse tipo de orçamento, visto que eles podem adotar a nova política, porém apoiam parcialmente seus componentes centrais, o que geraria resultados mais tímidos ou poucas diferenças em relação ao modelo de planejamento orçamentário tradicional. Nesse caso, os gestores municipais limitam o tempo e recursos financeiros gastos com a adoção de novas políticas orçamentárias.

Carvalho e Felgueiras (2000, p. 66), compartilham da mesma ideia, "O alcance do OP também é limitado pelas resistências internas aos governos em efetivamente partilhar o poder, em submeter às decisões técnicas e políticas à avaliação popular. Mesmo governos que se dizem comprometidos com a participação encontram muitas resistências internas a efetivá-la [...]”. E ainda, Sánchez (2002), relaciona algumas concepções contrárias ao orçamento participativo, como o aumento da lentidão e os custos na tomada de decisões; nem todos cidadãos possuem conhecimento sobre gestão pública; os participantes podem defender interesses particulares, em detrimento dos interesses coletivos; e, também, podem considerar apenas o curto prazo para tomar decisões. Portanto, existem fatores contrários à implantação do orçamento participativo, exigindo estudos anteriores ao uso desse modelo orçamentário, para reduzir as dificuldades.

Inserido nesse cenário, é que pretende-se desenvolver o estudo, então proposto, de acordo com os procedimentos metodológicos a seguir descritos.

\section{METODOLOGIA}

Quanto ao método e a forma de abordar o problema, o presente estudo pode ser considerado qualiquantitativo. Richardson et al. (2007) classificam a pesquisa em qualitativa e quantitativa. A primeira baseia-se em análises que não utilizam instrumentos estatísticos. Já a segunda, faz uso desses instrumentos tanto na coleta como no tratamento dos dados, medindo relações entre as variáveis.

Em relação aos objetivos da pesquisa, a pesquisa possui caráter exploratório-descritivo, uma vez que busca tornar o problema mais claro, familiar e proporcionar maior conhecimento sobre a temática do orçamento participativo e, ao mesmo tempo, objetivo descrever um fenômeno, isto é, o processo de realização do orçamento participativo.

A pesquisa exploratória, segundo Gil (2002, p.41) "têm como objetivo proporcionar maior familiaridade com o problema com vistas a torná-lo mais explícito ou a constituir hipóteses". Já a 
pesquisa descritiva, ainda de acordo com Gil (2002, p.42), "tem como objetivo primordial a descrição das características de determinada população ou fenômeno ou, então, o estabelecimento de relações entre variáveis".

Para a coleta de informações, foi aplicado um questionário com amostra de eleitores do município, e também foi feita uma entrevista com o secretário de finanças da cidade, com vista a identificar possíveis formas de execução do orçamento participativo.

Para Gil (2002, p. 114), "por questionário entende-se um conjunto de questões que são respondidas por escrito pelo pesquisado. [...] Entrevista, por sua vez, pode ser entendida como a técnica que envolve duas pessoas numa situação 'face a face' e em que uma delas formula questões e a outra responde".

A entrevista foi do tipo focalizada, ou seja, enfoca um tema bem específico (GIL, 2008). As respostas da entrevista foram analisadas por meio da técnica de análise de conteúdo, a qual é um conjunto de instrumentos metodológicos que se aplica a discursos diversificados (BARDIN, 1977). 0 questionário foi composto por questões abertas e fechadas, e suas respostas foram interpretadas por técnicas estatísticas. As informações obtidas foram introduzidas e organizadas no Microsoft Excel, versão 2013, software que possibilitou a geração de gráficos e dados percentuais.

Para definição da amostra, foram utilizados os dados da última eleição em Apodi-RN, obtidos no site do TSE (Tribunal Superior Eleitoral), que contabilizou 29.033 eleitores. A definição da quantidade de questionários a serem aplicados foi feita a partir do cálculo amostral, sugerido por Santos (2017):

$$
n=\frac{N \cdot Z^{2} \cdot p \cdot(1-p)}{Z^{2} \cdot p \cdot(1-p)+e^{2} \cdot(N-1)}
$$

Onde:

$\mathrm{n}$ - amostra calculada

$\mathrm{N}$ - população (Tamanho do universo)

Z - variável normal padronizada associada ao nível de confiança

$\mathrm{p}$ - verdadeira probabilidade do evento

e - erro amostral

Para o universo, foi utilizado o número de eleitores da eleição de 2016, em um total de 29.033 eleitores. Adotou-se um nível de confiança de $95 \%$, sendo de $5 \%$ o erro amostral, o que resultado na aplicação de 380 questionários. A análise dos dados levantados por meio dos questionários e da entrevista será desenvolvida na próxima seção.

\section{RESULTADOS E DISCUSSÕES}

\subsection{Caracterização socioeconômica}

Nesta seção buscou-se, com a caracterização socioeconômica, identificar o perfil dos indivíduos para participarem do presente estudo, conforme figura a seguir. 


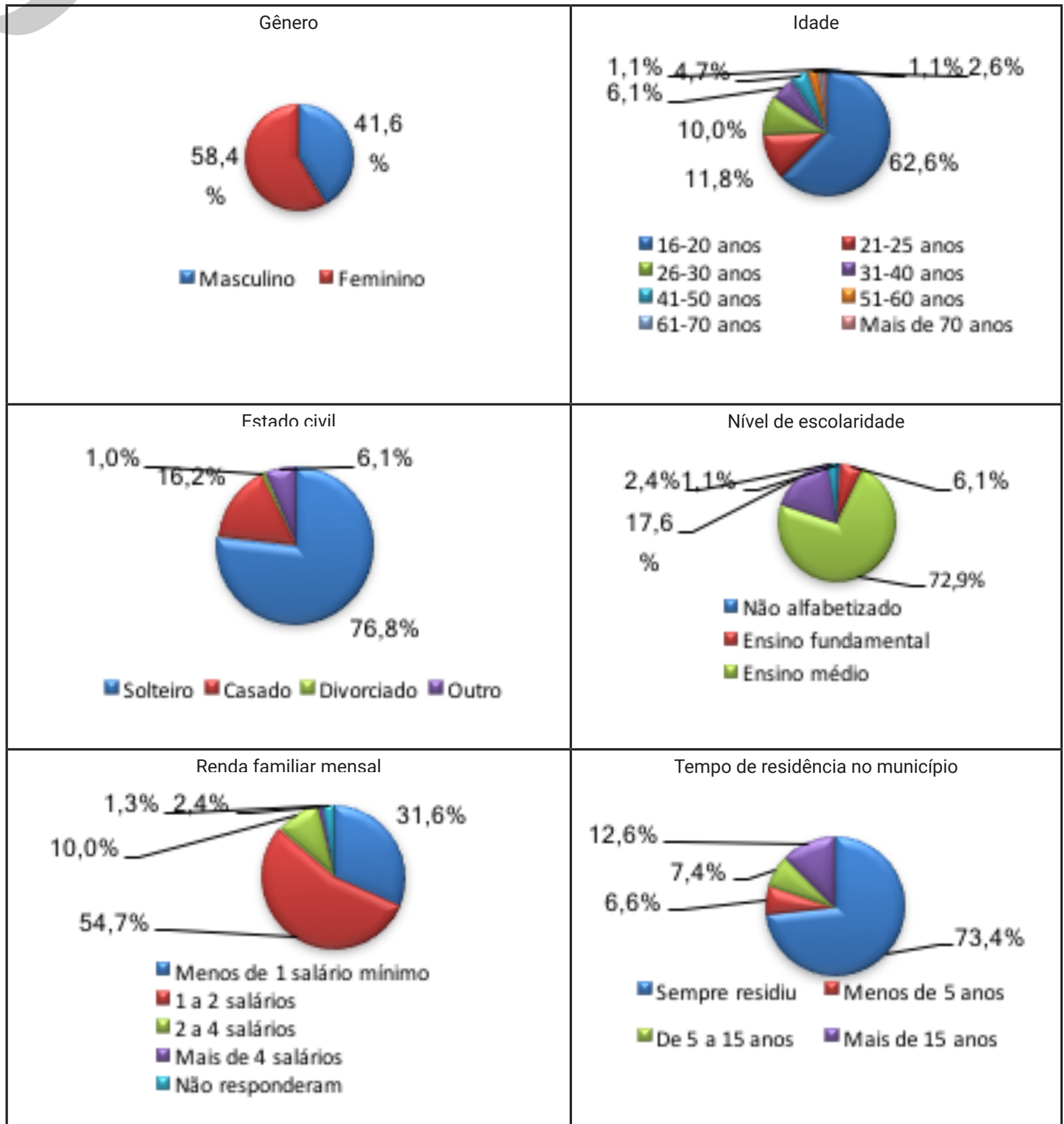

Figura 1 - Caracterização Sócioeconômica

Fonte: Autoria própria (2017).

Para isso foi questionado o gênero, o ano de nascimento, o estado civil, o nível de escolaridade, a renda familiar mensal, o tempo de residência na cidade de Apodi, além de se verificar se o respondente era, ou não, eleitor do município de Apodi, considerando, para essa pesquisa, apenas os que responderam afirmativamente a essa última pergunta. Ao todo, foram aplicados 380 questionários, buscando a maior diversidade possível entre os entrevistados, para garantir que os mesmos não fossem comprometidos.

Em relação ao gênero dos entrevistados, 58,4\% eram mulheres, e 41,6\%, são homens. Quanto à faixa etária, encontrou-se os seguintes resultados: $62,6 \%$ estão entre 16 e 20 anos; $11,8 \%$ correspondem a faixa etária entre 21 e 25 anos; de 26 a 30 anos foram entrevistados 10,0\% da amostra; $6,1 \%$ estão entre 31 a 40 anos; 4,7\% da amostra possui entre 41 a 50 anos; já entre as idades de 51 a 60 anos 


\section{ISSN - 2447-178X}

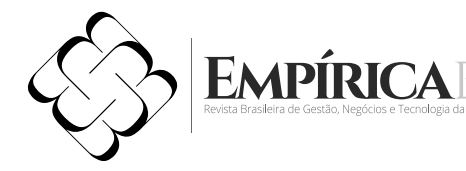

encontrou-se 2,6\% dos respondentes; e por fim, as faixas etárias de 61 a 70 anos, e com mais de 71 anos, representaram $1,1 \%$, para cada intervalo. 0 recorte da amostra, para responder ao questionário, partiu da idade mínima que permitisse ao cidadão ser eleitor, ou seja, abordou-se pessoas que já possuíam o direito de voto e, portanto, poderiam participar nas decisões políticas da cidade.

No que se refere ao estado civil, $76,3 \%$ dos entrevistados eram solteiros, justificando-se pela maioria (mais de 70\%) terem até 25 anos de idade. Já outros $16,1 \%$ são casados e 7,6\% responderam "divorciado" e "outros". Quanto ao nível de escolaridade, encontrou-se os seguintes resultados: 72,9\% possuem "ensino médio", mais uma vez, justificando-se pela faixa etária; $6,1 \%$ afirmaram possuir "ensino fundamental"; 1,1\% consideram-se "não alfabetizados"; $17,6 \%$ possuíam ensino superior e apenas $2,4 \%$ eram pós-graduados. São resultados que, aparentemente, correspondem com a realidade apodiense, já que na cidade possui poucos cursos superiores.

No que diz respeito à renda familiar mensal, mais de $54 \%$ responderam "de um a dois salários mínimos"; 31,6\% responderam que recebiam até um salário mínimo; 10\% afirmaram receber de dois até quatro salários mínimos e, um pouco mais de $1 \%$, ganhavam mais de quatro salários. Outra questão se referia ao tempo de residência em Apodi, quando verificou-se que 73,4\% sempre residiram; 12,6\% residem há mais de 15 anos; 7,4\% de 5 a 15 anos e 6,6\% menos de cinco anos. Por último, foi questionado se o entrevistado era eleitor de Apodi, sendo utilizado para essa pesquisa, apenas os que responderam sim.

\subsection{Percepção da população acerca do Orçamento Participativo}

A segunda parte do questionário referia-se à percepção da população em relação ao orçamento público, com questões abertas e fechadas, quando se buscou coletar opiniões acerca da implementação do orçamento participativo.

Quanto ao entendimento da população a respeito do orçamento público (Figura 2, seguinte), verificou-se que grande parcela da amostra não possuía conhecimento sobre o assunto, e outra parte significativa detém pouco conhecimento a respeito de orçamento, de forma que, apenas a minoria afirmou entender o funcionamento do orçamento municipal. A diferença entre esses percentuais sugere que o planejamento orçamentário da cidade de Apodi segue o modelo tradicional, isto é, a gestão pública municipal é a única responsável por aplicar os recursos públicos, de modo que a construção do orçamento público não pode ser considerada um modelo de orçamento participativo. 


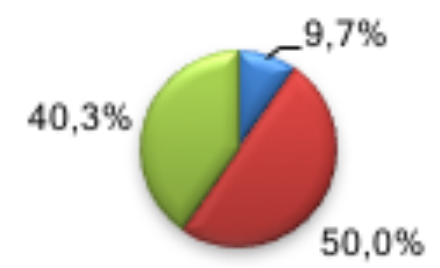

\section{USim $\mathbf{m}$ Nåo $\mathbf{M}$ Tenho pouca noçăo do assunto}

Figura 2 - Conhecimento a respeito do Orçamento Público

Fonte: Autoria própria (2017).

O cenário descrito anteriormente fica mais evidente quando os cidadãos são questionados se acompanham o orçamento público municipal (Figura 3). Para tal questão, apenas 2,1\% da amostra responderam positivamente, enquanto $23,7 \%$ acompanhavam, às vezes, o orçamento municipal. Essa questão pode representar a falta de interesse da população, como também o pouco acesso que a população tem ao orçamento municipal. Aqueles que responderam "Sim" ou "Às vezes" utilizam os seguintes meios, para tal acompanhamento: rádio (50\%), audiências públicas $(11,2 \%)$, na internet, por exemplo, acesso a blogs políticos (26,5\%), redes sociais (10,2\%), e pessoalmente (2\%). É importante esclarecer que a cidade não possui canais de TV, portanto, programas de rádio são muito utilizados para divulgação e discussões por parte da Prefeitura Municipal de Apodi.

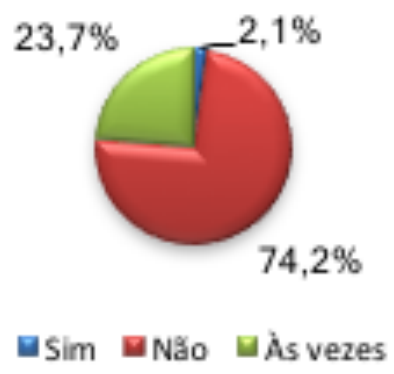

Fonte: Autoria própria (2017).

Quando questionados sobre a importância da participação da população na elaboração do orçamento público (Figura 4), a quase totalidade dos respondentes disseram que sim, ou seja, 93,9\% dos abordados. As justificativas dadas por eles se assemelham aos principais benefícios da inclusão da população no planejamento orçamentário, que são: proporcionar gestão democrática; despertar consciência cidadã; promover maior fiscalização dos gastos públicos, entre outros. Essas respostas concordam com Paludo (2013, p.162), quando o autor diz que "essa técnica estimula o exercício da cidadania, o compromisso da população com o bem público, e gera corresponsabilização entre governo e sociedade sobre a gestão dos recursos públicos". Tem-se, portanto, que, mesmo a população não tendo muito conhecimento a respeito do orçamento público, acreditam que a implementação deste modelo, na cidade, traria melhorias aos cidadãos. 


\section{ISSN - 2447-178X}

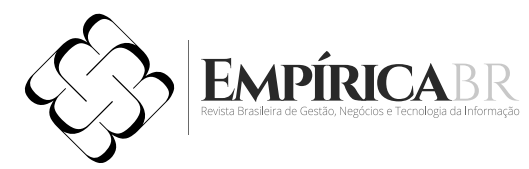

Cerca de $4 \%$ da amostra não considerava a participação popular importante, devido a acreditarem que o gestor municipal toma as melhores decisões, e que a sociedade não possui conhecimento adequado para essa gestão democrática e, ainda, afirmam que a opinião das pessoas não seria levada em consideração. Outros $2,1 \%$ não responderam a questão.

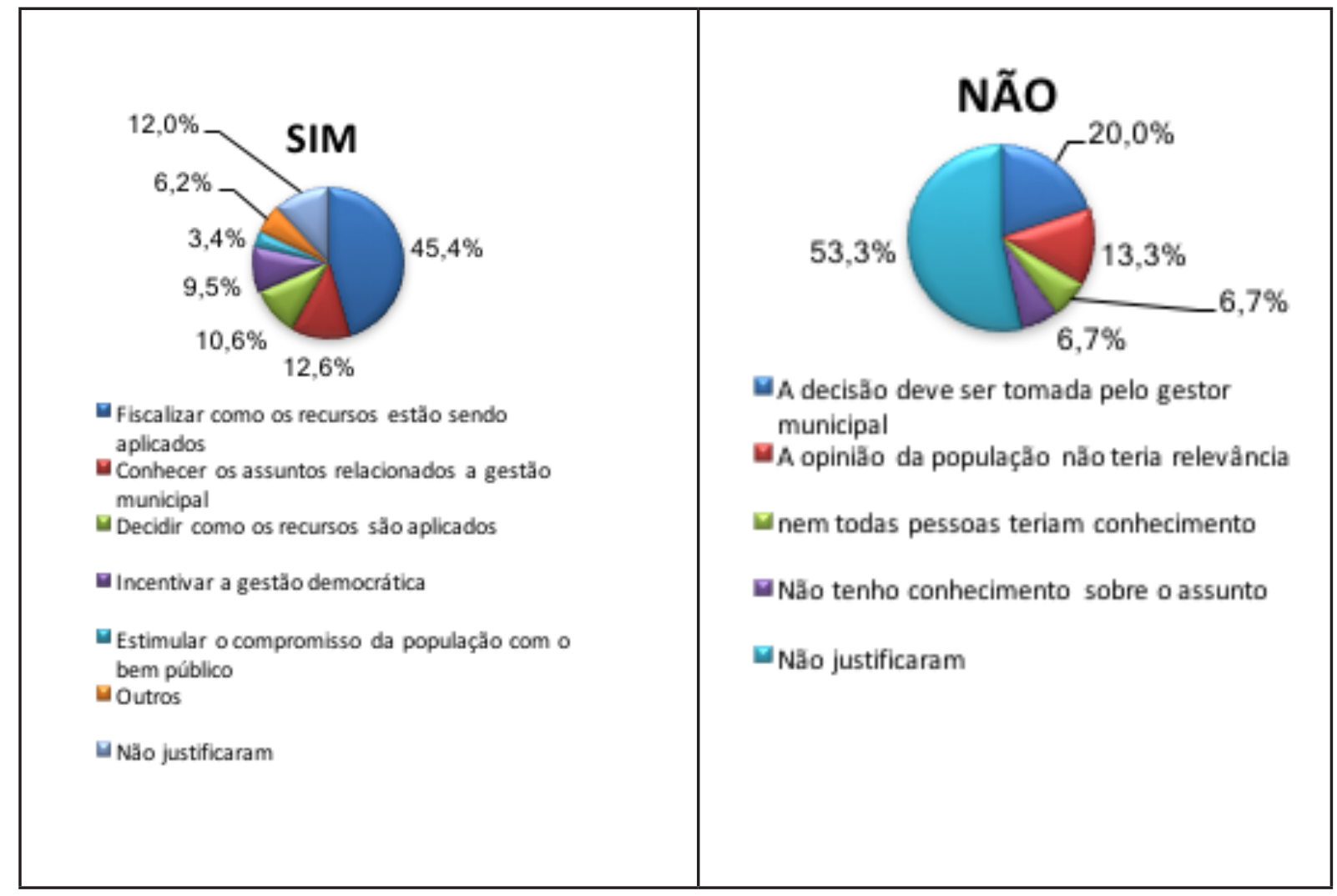

Figura 4 - Importância da participação popular no orçamento público

Fonte: Autoria própria (2017).

Na sequência, buscou-se verificar se a população conhece o termo "orçamento participativo" (Figura 5), constatando-se que a maioria não possui nenhum conhecimento sobre o tema, o que indica que esse assunto não é discutido pelos gestores municipais e que a população não participa do planejamento orçamentário. 


\section{ISSN - 2447-178X}
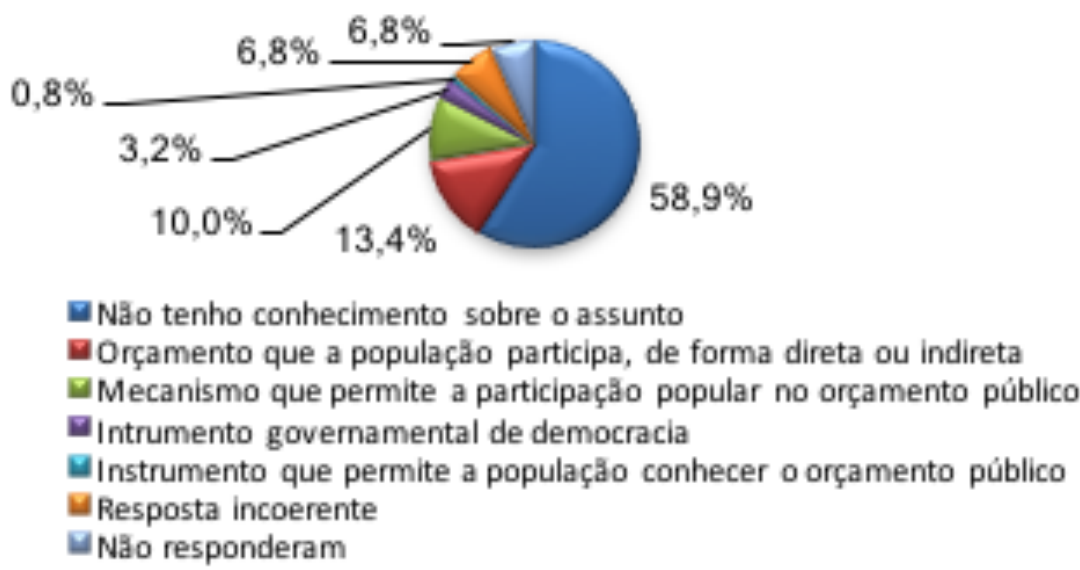

Figura 5 - Conhecimento sobre Orçamento Participativo

Fonte: Autoria própria (2017).

Apesar de grande parte da população considerar importante sua participação no planejamento orçamentário, o seu conhecimento sobre o assunto ainda é precário, o que pode sugerir a necessidade de mais empenho por parte da prefeitura para integrar a sociedade nas decisões orçamentárias, como formas de participação. As demais repostas afirmaram que se trata de um instrumento participativo, por meio do qual a sociedade passa a atuar de forma mais ativa. Percebe-se, a partir destes resultados, que as respostas dadas estão de acordo com a teoria, visto que, para Carvalho (2014), "o orçamento participativo é um mecanismo governamental de democracia participativa que permite aos cidadãos influenciar ou decidir sobre os orçamentos públicos".

A figura 6 demonstra a colaboração da população com o orçamento público. Verificou-se que 82,9\% da amostra não colabora com o planejamento orçamentário; outros 54 respondentes, correspondendo a $14,2 \%$, disseram participar. Porém, desse resultado, 51 indivíduos apresentaram respostas incoerentes e/ou não justificaram. Por fim, cerca de $3 \%$ não responderam à questão.

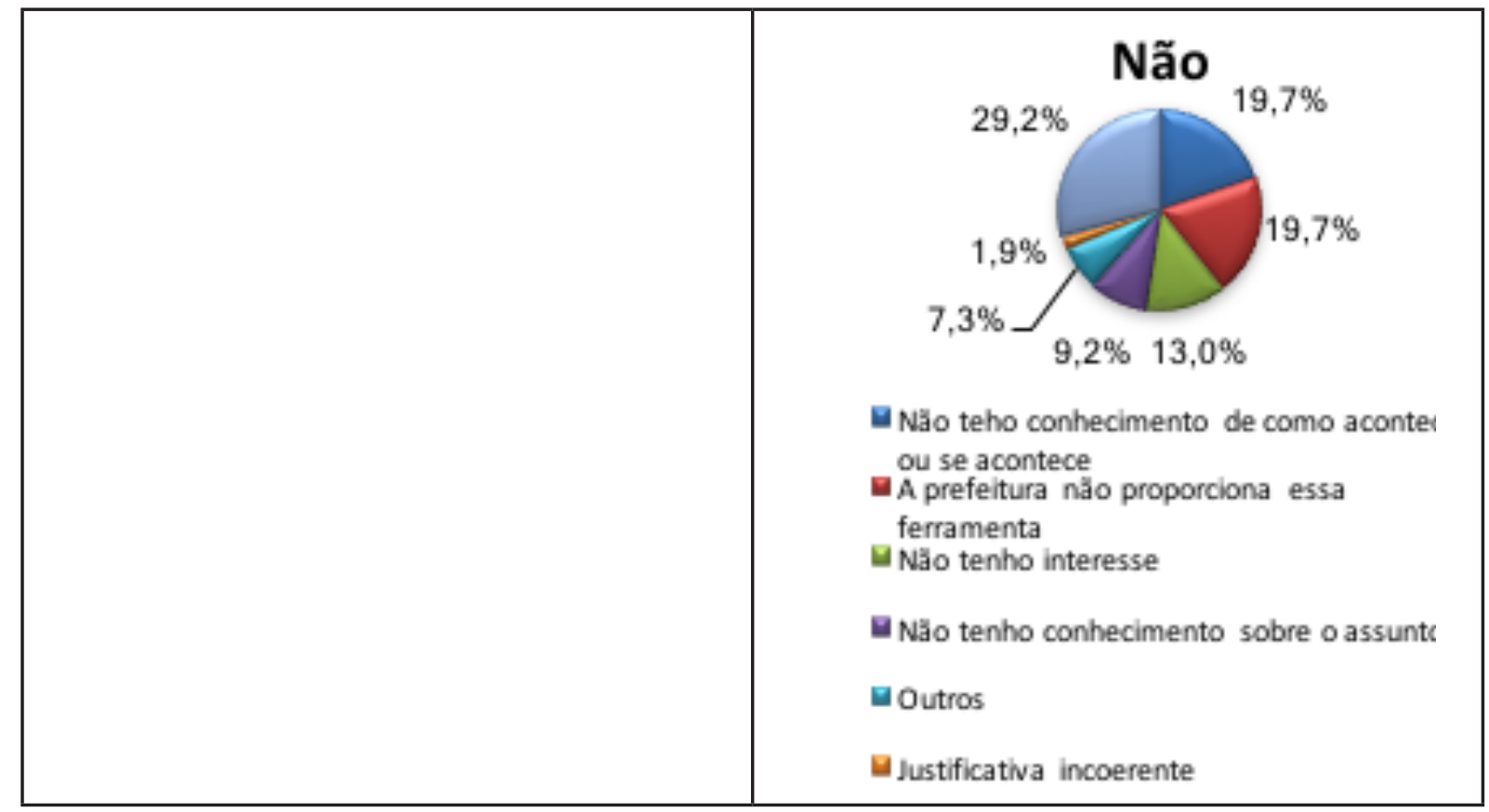

Figura 6 - Colaboração da população com o Orçamento Participativo 
No que diz respeito ao nível de interesse em colaborar com o processo de orçamento participativo, $54,5 \%$ da amostra respondeu não ter interesse em colaborar. Desses, a maioria afirmou não ter interesse por questões políticas. Outros $40,8 \%$ disseram se interessar em participar do orçamento público, em colaboração com a prefeitura; enquanto algo próximo de $5 \%$ não respondeu à pergunta. A falta de interesse dos cidadãos pode ser justificada pela cultura brasileira, na qual a sociedade não se envolve diretamente com as decisões políticas, sendo participantes passivos, e, talvez, pelo fato de que o conhecimento sobre esse assunto ainda é restrito no órgão público, o que levaria, então, à população não possuir interesse em participar, por não conhecerem do que se trata e, consequentemente, seus benefícios. Na figura 7 é possível encontrar as justificativas dadas pelos sujeitos da pesquisa.

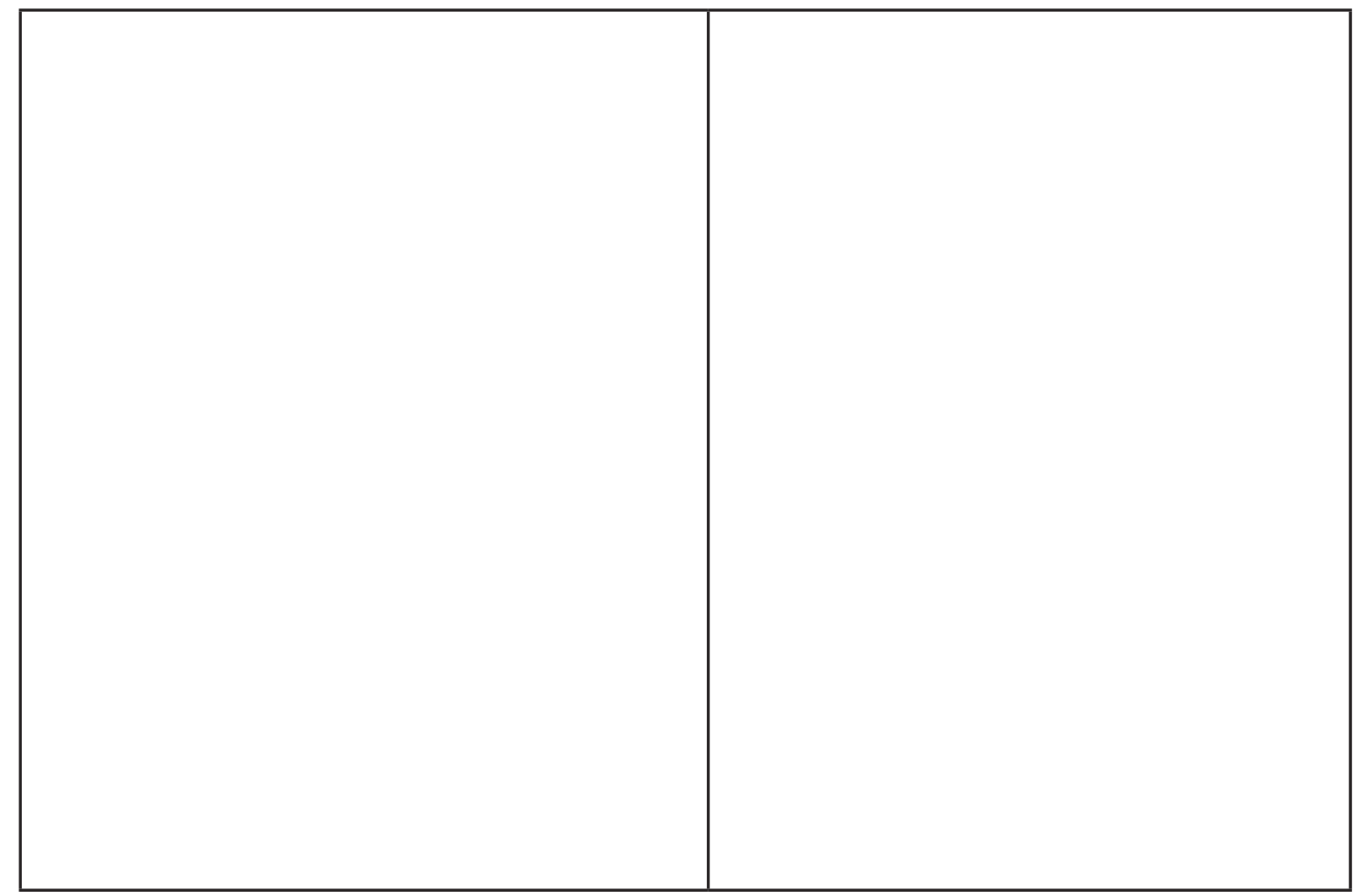

Figura 7 - Interesse em colaborar com o Orçamento Participativo Fonte: Autoria própria (2017)

Dentro das possíveis causas que levariam o cidadão a participar do orçamento municipal, $68,16 \%$ escolheram "necessidades da rua, bairro ou cidade"; $23,42 \%$ selecionaram "interesse pessoais, familiares ou amigos"; $1,1 \%$ escolheram a opção "interesses de grupos específicos", como grupos profissionais e campanhas beneficentes, e outros $2,4 \%$ citaram "outros", como interesses partidários, interesses de comunidades rurais, ou mesmo exigir maior compromisso dos políticos. Observa-se, então, que a população interessada preocupa-se, principalmente, com assuntos coletivos, o que sugere à prefeitura identificar quais são as principais reivindicações de cada bairro. 
Em relação ao fato de a Prefeitura Municipal

$6 !$
$d t$
$q i$
pi
pr
re

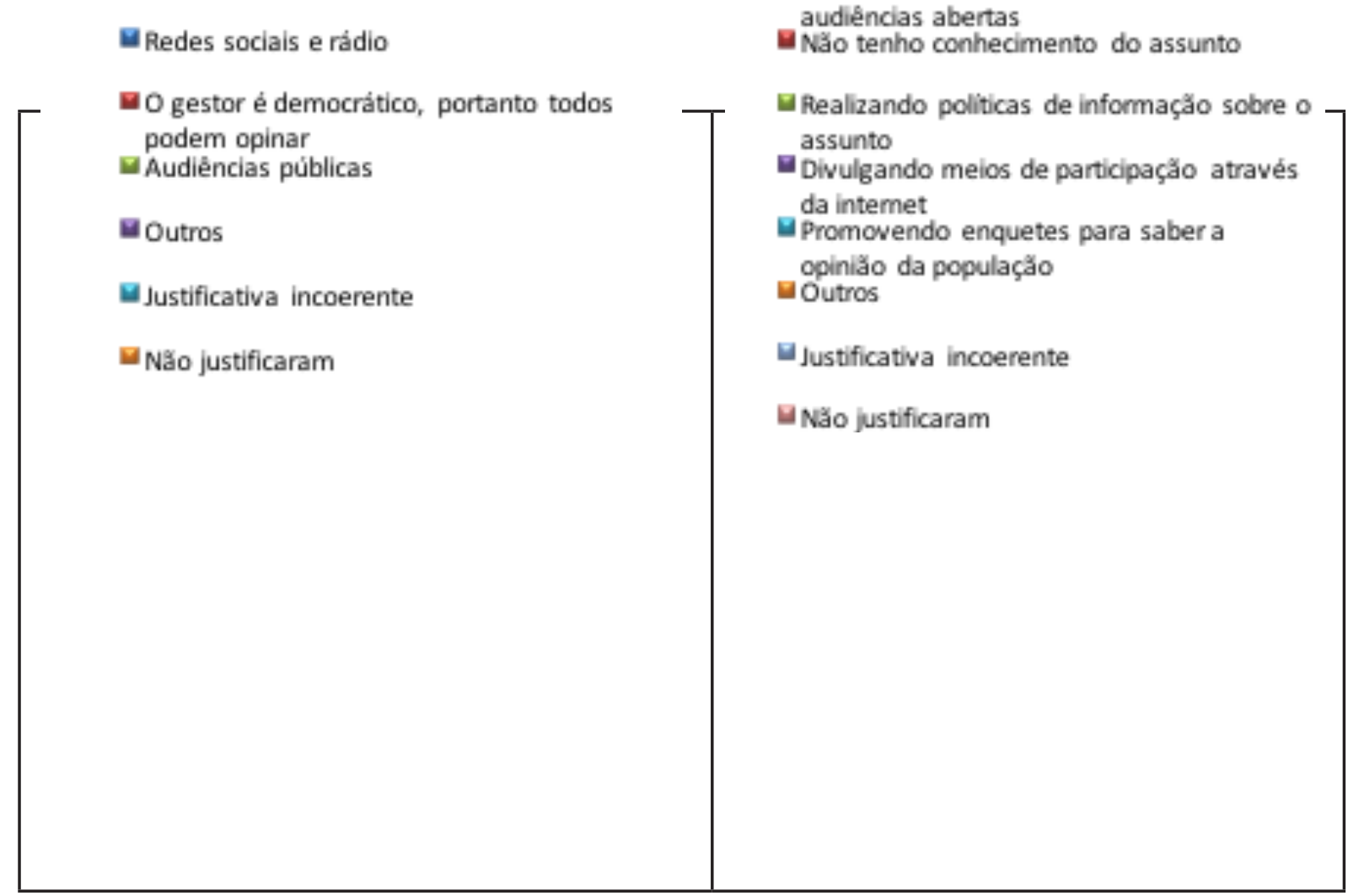

Figura 8 - A Prefeitura proporciona meios de participar do Orçamento Público?

Fonte: Autoria própria (2017)

Ao serem questionados se a prefeitura incentiva à sociedade a participar do orçamento público, percebe-se que a maioria respondeu "Não", corroborando com a questão acima. Apenas 17,6\% afirmaram que a prefeitura incentiva, no entanto, mais que da metade não justificou sua resposta, ao serem questionados como a prefeitura incentiva a sociedade a colaborar com as decisões orçamentárias. Outros $76,8 \%$ da amostra disseram que não ocorre incentivo por parte da gestão municipal, por ser um tema ainda restrito na administração municipal, e que precisaria de ações para incluir a sociedade nessas decisões. Um pouco mais de $5 \%$ dos sujeitos abordados não responderam essa questão. As justificativas dadas pelos respondentes que afirmaram que a prefeitura incentiva à sociedade a participar do orçamento público; assim como as sugestões "de como deveria ser", dada por aqueles que discordam dessa afirmação, estão expostas na figura a seguir. 


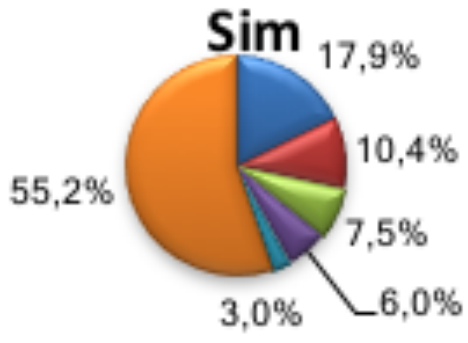

Por meio de audiências e programas de rádio

Mantendo a transparência e democracia nos seus atos

Promove campanhas de divulgaçåo

Por meio das midias sociais e pelo site da prefeitura

Justificativa incoerente

Nåo justificaram

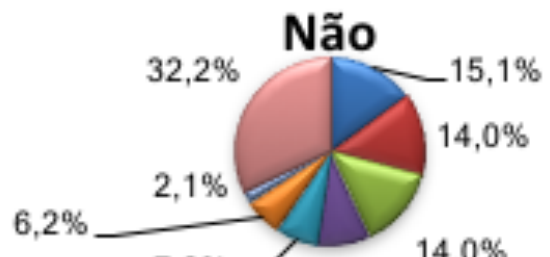

$7,2 \%$

$9,2 \%$

Nåo tenho conhecimento do assunto

Divulgando formas de participaçăo, em geral

Fazendo campanhas de incentivo

Mromovendo audiências abertas, reuniōes, assembleias

- Investindo em educaçåo política

Butros

Justificativa incoerente

Nå justificaram

Figura 9 - A Prefeitura incentiva à sociedade a participar do Orçamento Público?

Fonte: Autoria própria (2017).

Ao serem questionados se o orçamento participativo influencia na gestão democrática, a quase totalidade dos respondentes $(91,3 \%$ respondeu "sim"; $7,4 \%$ disseram não contribuire $1,3 \%$ não respondeu. 0 orçamento participativo é um importante fator para as decisões políticas serem democráticas, pois conta com as opiniões da população, sendo priorizadas as principais reivindicações e, dessa forma, a população conheceria e se envolveria mais com assuntos públicos, conforme apontado por Paludo (2013, p. 39) quando afirma que "o principal benefício do Orçamento Participativo é a democratização da relação do Estado-sociedade com fortalecimento da democracia. Nesse processo, o cidadão deixa de ser um simples coadjuvante para ser protagonista da gestão pública".

Ao questionar sobre quais benefícios a implementação do modelo orçamentário participativo traria para a sociedade, a pesquisa obteve respostas diversas: $22,9 \%$ dos respondentes acreditam que, com a participação da sociedade no orçamento, a cidade seria mais desenvolvida; $13,9 \%$ disseram que a população teria mais conhecimento a respeito dos gastos públicos e, também, de como os recursos públicos estão sendo aplicados; $13,2 \%$ apontaram a gestão democrática como principal benefício; $10 \%$ afirmaram que a população tem mais direito que a prefeitura para decidir como os recursos serão aplicados, já que é conhecedora dos principais problemas; além da redução dos índices de corrupção, que foi apontada por 1,6\% dos cidadãos abordados. Já 11,1\% disseram não conhecer o assunto e, portanto, não podem dizer quais são os benefícios; e, quase $19 \%$, não responderam à questão. Como já foi dito, o orçamento participativo atua como importante instrumento democrático, dando poder aos cidadãos para participarem das decisões políticas; contribui com a função educativa do governo, no 
momento em que a sociedade passa a conhecer como são efetuados os gastos públicos e, também, atı

(Fi

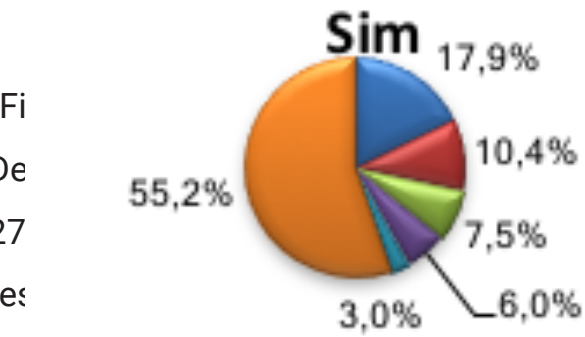

pa por meio de audiências e programas de rádio

po

pa

ga

res $\square$ Por meio das mídias sociais e pelo site da

do prefeitura

Justificativa incoerente

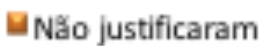

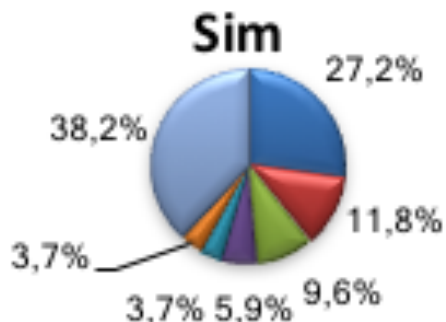

- Näo existiria acordo, ocasionando demora na tomada de decišres

QDevido a cultura apodiense, iria prevalecer pensamentos partidários

Miria prevalecer interesses pessoais

As pessoas nåo teriam conhecimento

MFalta interesse da populaçăo

Mustificativa incoerente

অ Nåo justificaram

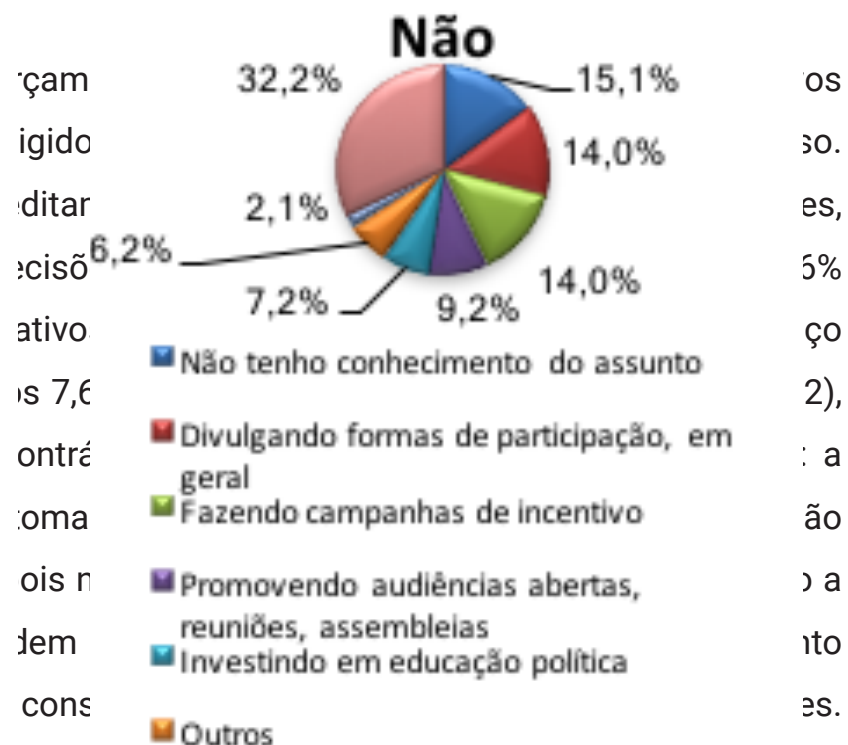

$\square$ Justificativa incoerente

MNa justificaram

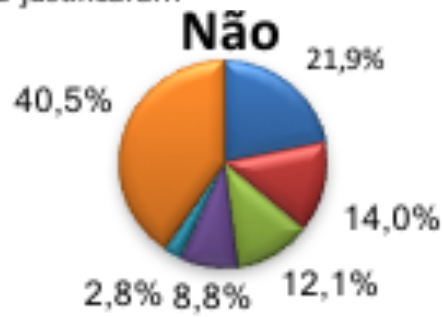

U Iria melhorar a gestằ municipal

As decis Des de imvestimento seriam

tomadas de forma mais eficiente

$\square$ A gestăo seria mais democrática

- Traria mais conhecimento para populaçăo a respeito do assunto

Outros

๑ Năo justificaram

Figura 10 - Existiria aspectos negativos na implementação do OP?

Fonte: Autoria própria (2017).

Para a conclusão da pesquisa, ainda foi realizada uma entrevista com o secretário municipal de finanças a respeito do orçamento público. 0 secretário afirmou que para a elaboração do orçamento, as propostas foram discutidas com a equipe de governo em todas as áreas e, posteriormente, foram realizadas audiências públicas e reuniões com conselhos representativos da sociedade. No entanto, a realização de audiências públicas é obrigatória, e por meio dos questionários aplicados, verificou-se 
que poucos cidadãos conhecem o tema. O secretário esclareceu que a participação popular se dá, justamente, nas audiências públicas e nas reuniões dos conselhos, em que a opinião da população é solicitada.

Ao ser questionado sobre quais dificuldades a prefeitura enfrenta para implementar o orçamento participativo, ele apontou a extensão territorial, já que o município possui muitas comunidades rurais. Ainda para o entrevistado, o orçamento participativo apresenta apenas aspectos positivos, pois é mais uma forma de ter uma gestão municipal transparente e com a interação dos cidadãos em todos os processos de elaboração do orçamento público, e que esse modelo de orçamento afeta de maneira positiva a gestão pública municipal, pois a participação cidadã é vista como um processo capaz de gerar uma nova dinâmica de organização social. Assim, após a discussão e análise de dados aqui realizada, parte-se, na sequência, para as considerações finais do estudo.

\section{CONCLUSÃO}

Compreender como a democracia pode influenciar nas decisões políticas é o primeiro passo para conscientizar a população a respeito da importância de sua participação na gestão municipal. No âmbito orçamentário, o modelo do orçamento participativo se mostra como uma importante ferramenta para incluir a sociedade na gestão pública. Inserido nesse cenário, o estudo apresentado buscou analisar o contexto de participação da população no planejamento orçamentário do município de Apodi-RN. Além disso, nos objetivos específicos, buscou-se verificar o modelo de elaboração do orçamento público no município; o envolvimento da população no planejamento orçamentário; a existência de ações voltadas ao incentivo à participação da população e, também, a expectativa de aspectos positivos e negativos gerados pela implementação do orçamento participativo em Apodi-RN.

Para atingir o primeiro objetivo específico, foram expostos os tipos de orçamentos e princípios, o ciclo orçamentário vigente no Brasil, o conceito e as características do orçamento participativo, constatando-se que Apodi-RN segue o modelo do orçamento programa, no qual o planejamento está ligado à metas e resultados, com a pretensão de ser eficaz e eficiente.

Em relação ao segundo objetivo específico, foi abordado no estudo, o uso do orçamento participativo como instrumento de democracia e, também, como função educativa, no papel de educar os cidadãos para se interessarem pelas decisões coletivas. Sabendo que o orçamento participativo é uma nova técnica de elaboração do orçamento público, e que possui como objetivo a atuação mais ativa da sociedade nas decisões dos recursos públicos, no município de Apodi-RN, não é utilizado o orçamento participativo propriamente dito, uma vez que as formas de participação da sociedade, proporcionadas pela prefeitura municipal, ainda são ineficientes e grande parte da sociedade não contribui na elaboração do orçamento público. Acredita-se, contudo, que a mudança para o modelo de orçamento participativo exige uma transformação na cultura da sociedade, e exige, ao mesmo tempo, interesse por parte da população e disposição da gestão municipal para implementar o novo modelo.

Quanto ao terceiro objetivo específico, buscou-se identificar as ações de incentivo à participação popular no planejamento orçamentário fornecido pela prefeitura municipal de Apodi-RN, verificando-se 


\section{ISSN - 2447-178X}

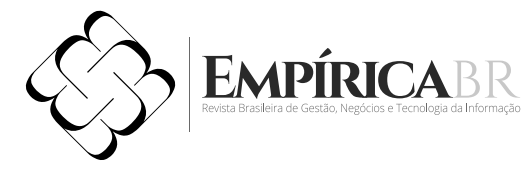

que os meios de participação ainda são poucos e não atingem grande parte dos cidadãos. Além disso, ficou comprovado à falta interesse da sociedade nos assuntos políticos. A gestão municipal, no entanto, mostrou interesse em aplicar um planejamento orçamentário mais democrático. Esse interesse parece incoerente com um cenário que demonstra decisões centralizadas, no âmbito orçamentário, por parte da prefeitura, e que esta não fornece meios de inclusão da sociedade, não investindo, por exemplo, em divulgação e realização de audiências públicas ou reuniões de bairros a fim de esclarecer a importância da inclusão da sociedade na gestão pública. As práticas de inclusão dos cidadãos no planejamento orçamentário, provavelmente, só alcançarão resultado positivo se a administração pública obtiver o interesse da sociedade em assuntos políticos, e, para isso, é preciso mostrar que os objetivos coletivos são conseguidos com a participação de todos.

Referente aos aspectos positivos da implantação do orçamento participativo, a população acredita que as decisões a respeito dos recursos públicos seriam tomadas de forma mais eficiente; a gestão pública municipal seria mais democrática; a sociedade passaria a conhecer mais o assunto e a cidade seria mais desenvolvida. Em tese, são melhorias que uma gestão integrada com a sociedade pode representar, já que a sociedade poderia priorizar suas necessidades e solicitar o investimento público para atendê-las. Também identificou-se aspectos negativos, como a demora na tomada de decisões, pois é preciso realizar reuniões e pesquisas a fim de encontrar uma solução comum, que corresponda ao interesse da maioria. Além desse, pode ocorrer predominância de interesses pessoais e de interesses partidários, em detrimento do interesse coletivo. Os entrevistados acreditam que a maioria dos cidadãos é desqualificada para decidirem sobre o orçamento público, e não possui interesse nesse assunto.

Dessa forma, constatou-se que a população desconhece a proposta do orçamento participativo e não tem interesse em assuntos políticos, e, portanto, não participam da elaboração do orçamento público, apesar de a prefeitura municipal demonstrar interesse em integrar a população no planejamento orçamentário. A partir disso, parece relevante o investimento, por parte da gestão municipal, em educação política, assim como em divulgação das formas de participação popular.

Quanto às limitações encontradas durante a realização do presente estudo é possível mencionar que, alguns cidadãos, apesar de residirem no município de Apodi-RN, não são eleitores do município e, por isso, foram excluídos do estudo. Outra restrição imposta à coleta de dados foi à falta de conhecimento dos respondentes da pesquisa em relação ao assunto em estudo, o que, por sua vez, gerou certo número de resposta sem a devida justificativa.

Por fim, as questões tratadas nesse estudo não esgotam o tema, de maneira que os resultados aqui obtidos podem servir como base para futuras pesquisas que possam contribuir para o desenvolvimento de uma sociedade mais democrática. Pesquisas que possam identificar estratégias de implantação do orçamento participativo municipal ou que possam realizar estudos comparativos entre cidades do Rio Grande do Norte, parecem ser um caminho a seguir em futuros estudos. 


\section{REFERÊNCIAS}

1. ALMEIDA, Rita de Cássia. A questão hídrica na gestão urbana participativa: o caso do orçamento participativo do município de São Carlos, SP. 2005. 178 f. Tese (Doutorado em Ciências da Engenharia Ambiental). Escola de Engenharia de São Carlos. Universidade de São Paulo, São Paulo.

2. BARDIN, Laurence. Análise de conteúdo. Lisboa: Edições 70, 1977.

3. BENEVIDES, M. V. A cidadania ativa, referendo, plebiscito e iniciativa popular. São Paulo, SP, Ática, 1996.

4. CARVALHO, Deusvaldo. Orçamento e contabilidade pública. $6^{\text {a }}$ ed. Rio de Janeiro: Elsevier, 2014. (Provas e concursos).

5. CARVAlHO, Maria do Carmo A. A.; FELgUeIRAS, Débora. Orçamento Participativo no ABC. Mauá, Ribeirão Pires e Santo André. São Paulo: Pólis, 2000. 80p. (Publicações Pólis, 34).

6. Constituição Federal/1988. Disponível em: <http://www.planalto.gov.br/ccivil_03/constituicao/ constituicao.htm> Acesso em: 3 jun. 2017.

7. COSTA, André Galindo. Conselhos de políticas públicas e associações de moradores: estudo de caso do orçamento participativo no município de São Carlos. 2014. 164 f. Dissertação (Mestrado em Ciências do Programa de Pós-Graduação em Mudança Social e Participação Política). Escola de Artes, Ciências e Humanidades. Universidade de São Paulo. São Paulo.

8. Estatuto das cidades. Disponível em <http://www.planalto.gov.br/ccivil_03/leis/LEIS_2001/ L10257.htm>. Acesso em: 4 jun. 2017.

9. FONSECA, Jumária Fernandes Ribeiro. O Orçamento Participativo e a Gestão Democrática de Goiânia. Dissertação (Mestrado em Desenvolvimento e Planejamento Territorial). Programa de PósGraduação em Desenvolvimento e Planejamento Territorial da Universidade Católica de Goiás. Goiânia, 2009.

10. FREY, Klaus. Capital social, comunidade e democracia. Política e Sociedade. Florianópolis, v. 1, n.2, p. 157-187, 2003.

11. GIL, Antônio Carlos. Como elaborar projetos de pesquisa. 4a ${ }^{a}$. ed. São Paulo: Atlas, 2002.

12. GIL, Antônio Carlos. Métodos e técnicas de pesquisa social. $6^{\mathrm{a}}$ ed. São Paulo: Atlas, 2008.

13. IBGE. Disponível em: $<$ http://cidades.ibge.gov.br/xtras/perfil.php?lang=\&codmun=240100\&sea

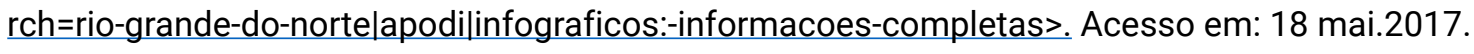

14. Lei de Responsabilidade Fiscal. Disponível em: <http://www.planalto.gov.br/ccivil_03/leis/LCP/ Lcp101.htm>. Acesso em: 3 jun. 2017. 


\section{ISSN - 2447-178X}

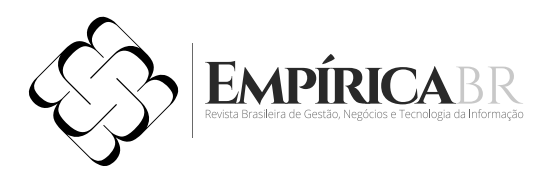

15. OLIVEIRA, Osmany Porto. Embaixadores da participação: A difusão internacional do Orçamento Participativo a partir do Brasil. 2013. 292 f. Tese (Doutorado em Ciência Política). Universidade de São Paulo, São Paulo.

16. PALUDO, Augustinho Vicente. Administração Pública. $3^{\text {a }}$ ed. Rio de Janeiro: Elsevier, 2013.

17. PALUDO, Augustinho Vicente. Orçamento público e administração financeira e orçamentária e LRF. 4ª ed. Rio de Janeiro: Elsevier, 2013.

18. RICHARDSON et al. Pesquisa social: métodos e técnicas. $3^{\mathrm{a}}$ ed. rev. ampl. São Paulo: Atlas, 2007.

19. SÁNCHES, Félix. Orçamento Participativo: teoria e prática. São Paulo: Cortez, 2002.

20. SANTOS, Glauber Eduardo de Oliveira. Cálculo amostral: calculadora on-line. Disponível em: <http://www.calculoamostral.vai.la>. Acesso em: 25 mai. 2017.

21. SANTOS, Rita de Cássia Leal Fonseca. Plano Plurianual e Orçamento Público. $2^{\mathrm{a}}$ ed. Reimp. Florianopólis: Departamento de Ciências da Administração/UFSC; [Brasília]: CAPES: UAB, 2012.

22. SILVA, Lino Martins. Contabilidade Governamental: Um enfoque administrativo da nova contabilidade pública. $8^{\text {a }}$ ed. São Paulo: Atlas, 2009.

23. SOUZA, Celina. Construção e consolidação de instituições democráticas: papel do orçamento participativo. São Paulo em perspectiva. São Paulo. Ano 15, nº 4. 2001.

24. STRECK, Danilo R. Educação para um novo contrato social. Petrópolis, RJ: Vozes, 2003.

25. TRIBUNAL SUPERIOR ELEITORAL - TSE. Disponível em: <http://www.tse.jus.br/eleicoes/ estatisticas/estatisticas-eleitorais-2016/eleicoes-2016>. Acesso em: 25 mai. 2017.

26. VILLAS-BÔAS, Renata J.A. Participação popular nos governos locais. Revista Pólis. N. 14, 1994.

27. WAMPLER, B. Participatory Budgeting in Brazil: Contestation, Cooperation, and Accountability. University Park: Pennsylvania State Press, 2007 